\title{
Relationship of runoff, erosion and sediment yield to weather types in the Iberian Peninsula
}

Nadal-Romero, E. ${ }^{\text {a,b }}$, González-Hidalgo, J.C. ${ }^{\text {a }}$, Cortesi, N. ${ }^{\text {a }}$, Desir, G. ${ }^{\text {c }}$, Gómez, J.A. ${ }^{\text {, }}$ Lasanta, T. e, Lucía, A. ., Marín, C. ${ }^{\text {, }}$, Martínez-Murillo, J.F. ${ }^{\text {g }}$, Pacheco, E. ${ }^{\text {h }}$, RodríguezBlanco, M.L. ${ }^{\mathrm{i}}$, Romero Díaz, A. ${ }^{\mathrm{j}}$, Ruiz-Sinoga, J.D. ${ }^{\mathrm{g}}$ Taguas, T. ${ }^{\mathrm{k}}$, Taboada-Castro M. ${ }^{\mathrm{i}}$, Taboada-Castro M.T. ${ }^{\text {i }}$, Úbeda, X. ${ }^{\text {h }}$ Zabaleta, A. ${ }^{1}$

a Dep. Geografía. Instituto Universitario de Ciencias Ambientales (IUCA). Universidad de Zaragoza. Pedro Cerbuna, 12. 50009, Zaragoza (Spain).estelanr@unizar.es, jcgh@unizar.es_(+3497676100ext.843900)

$b$ Institute for Biodiversity and Ecosystem Dynamics. IBED. University van Amsterdam, Amsterdam (The Netherlands)

c Departamento de Ciencias de la Tierra. Universidad de Zaragoza, Zaragoza (Spain) d Instituto de Agricultura Sostenible-CSIC, Córdoba (Spain) e Instituto Pirenaico de Ecología-CSIC, Zaragoza (Spain) f Faculty of Science and Technology. Free University of Bolzano (Italy) g Departamento de Geografía, Grupo de Investigación Geografía Física y TerritorioRNM279, Andalucía Tech, Universidad de Málaga. Campus de Teatinos s/n, 29071 Málaga, Spain (Spain)

h Grup de Recerca Ambiental Mediterrània. Dep.de Geografia Física i AGR.

Universitat de Barcelona (Spain)

i Facultad de Ciencias. Universidade de A Coruña (Spain)

j Departamento de Geografía. Universidad de Murcia (Spain) 
k Esc. Técnica Sup. de I. Agronómica e I. de Montes. Dpto. Ingeniería Rural.

Universidad de Córdoba (Spain)

l Department of Geodynamics, University of the Basque Country, (UPV-EHU) (Spain)

*Corresponding authors. Tel.: +34 97676100 ext.843900; E-mail: estelanr@unizar.es (E. NadalRomero); E-mail: jcgh@unizar.es (J.C. González-Hidalgo). 


\section{ABSTRACT}

Precipitation has been recognized as one of the main factors driving soil erosion and sediment yield (SY), and its spatial and temporal variability is recognized as one of the main reasons for spatial and temporal analyses of soil erosion variability. The weather types (WTs) approach classifies the continuum of atmospheric circulation into a small number of categories or types and has been proven a good indicator of the spatial and temporal variability of precipitation. Thus, the main objective of this study is to analyze the relationship between WTs, runoff, soil erosion (measured in plots), and sediment yield (measured in catchments) in different areas of the Iberian Peninsula (IP) with the aim of detecting spatial variations in these relationships. To this end, hydrological and sediment information covering the IP from several Spanish research teams has been combined, and related with daily WTs estimated by using the NMC/NCAR 40-Year Reanalysis Project. The results show that, in general, a few WTs (particularly westerly, southwesterly and cyclonic) provide the largest amounts of precipitation; and southwesterly, northwesterly and westerly WTs play an important role in runoff generation, erosion and sediment yield as they coincide with the wettest WTs. However, this study highlights the spatial variability of erosion and sediment yield in the IP according to WT, differentiating (1) areas under the influence of north and/or northwesterly flows (the north coast of Cantabria and inland central areas), (2) areas under the influence of westerly, southwesterly and cyclonic WTs (western and southwestern IP), (3) areas in which erosion and sediment yield are controlled by easterly flows (Mediterranean coastland), and (4) lastly, a transitional zone in the inland northeast Ebro catchment, where we detected a high variability in the effects of WTs on erosion. Overall results suggest that the use of WTs derived from observed atmospheric pressure 
patterns could be a useful tool for inclusion in future projections of the spatial variability of erosion and sediment yield, as models capture pressure fields reliably.

Keywords: weather types; precipitation; runoff; erosion; sediment yield; spatial variability; Iberian Peninsula 


\section{Introduction}

Precipitation has been recognized as one of the main factors driving soil erosion for a long time (Wischmeier and Smith, 1958; Fournier, 1960), and soil erosion and sediment yield are the most important environmental problems worldwide (Bakker et al., 2007). The spatial and temporal distributions of soil erosion and sediment yield are difficult to assess because of high variability in precipitation on temporal and spatial scales, and this is particularly true in areas with a strongly contrasting seasonal rainfall regime and long history of human intervention, such as exists in the Mediterranean basin (Grove and Rackham, 2001).

Climate research has tried to analyze the variability of precipitation from several points of view, and among others, the weather types (WTs) seems to be one of the most promising. Basically, the WTs approach tries to categorize the continuum of atmospheric circulation into a small number of classes or types (Trigo and DaCamara, 2000), and it has been used extensively in different research areas: e.g., climatology, including droughts and precipitation patterns (Vicente-Serrano and López-Moreno, 2006; Fleig et al., 2011; Rust et al., 2013), temperature (Piotrowicz and Szlagor, 2013) and snow dynamics (López-Moreno and Vicente-Serrano, 2007; Biggs and Atkinson, 2011), air quality (Fraile et al., 2013; Vanos et al., 2014), hydrology and floods (Andrade et al., 2011; Pattison and Lane, 2012; Wilby and Quinn, 2013; Foulds et al., 2014), agriculture (Lorenzo et al., 2013; Sturman and Quenol, 2013), and wildfire occurrence (Rivas-Soriano et al., 2013; Trigo et al., 2013). To our knowledge, little research has been conducted into the relationships between WTs and soil degradation by rainfall (e.g., Wilby et al., 1997; Fernández-Raga et al., 2010; Nadal-Romero et al., 2014), with promising results from these authors, who have identified different atmospheric patterns (i.e., WTs) relating to geomorphological processes. 
Precipitation in the IP exhibits high variability on spatial and temporal scales (de Castro et al., 2005; González-Hidalgo et al., 2011), and previous research has demonstrated the usefulness of the WT approach in determining its spatial and temporal distribution (Trigo and DaCamara, 2000; Cortesi et al., 2013, 2014). These studies have shown that high amounts of monthly, seasonal, and annual precipitation are caused by a few WTs; that precipitation depends on more WTs to the west than to the east of the IP; and lastly, they found that the most prominent WTs for generating rainfall vary from region to region and particularly along the Mediterranean coastland, the precipitation depends on only a few WTs that usually affect small areas.

Soil degradation in the IP has been the subject of a great deal of research over the last 30 years (see review in García-Ruiz and López-Bermúdez, 2009), and the results show a high spatial and temporal variability of soil erosion processes (at plot level) and sediment yield (at catchment level), but the global view of this variability is not clear. Thus, this paper sets out to analyze the spatial variability of soil degradation in the IP from soil erosion and sediment yield through their relationships with the WTs. This was done by collecting data from various study areas and identifying the role played by different WTs in soil degradation.

In the IP, the WTs and precipitation exhibit a clear spatial pattern (Cortesi et al., 2013), thus in this study we analyse two hypotheses: (i) the existence of links between WTs and runoff, soil erosion, and sediment yield in the IP, and (ii) the emergence of spatial patterns in WTs, erosion, and sediment yield in the IP according to the spatial distribution of the relationship between WTs and precipitation.

\section{Materials and methods}

\subsection{Study area}


The IP extends over $582,000 \mathrm{~km}^{2}$ and is located in the extreme southwest of Europe. This location at the transition of the subtropical fringe makes it particularly interesting from a climatic point of view, not only because of its latitudinal position in the subtropical transition areas, but also because it is surrounded by two completely different water masses: the Atlantic Ocean in the north, west and southwest, and the Mediterranean Sea to the south and east. It is also interesting to note that, because of the west to east, and northwest to southwest distribution of the mountain ranges (Fig. 1 and 2), different rainfall areas can be distinguished in the IP for annual amounts and seasonal regimes: (i) in the north and northwestern areas, the typical mid-latitude oceanic rainfall regime occurs, with annual amounts $>800 \mathrm{~mm}$, a winter maximum, and no summer drought (in these areas rainfall is heavily dependent on Atlantic storms from the northwest); (ii) on the eastern Mediterranean fringe of IP, the annual amounts vary greatly (between 250 and $700 \mathrm{~mm}$ ), summer droughts and a bimodal rainfall regime with its maximum in autumn predominate (in these areas, precipitation depends to a large extent on eastern advections and local factors); (iii) and finally, in extended inland and southwestern areas of the IP, summer droughts occur, precipitation depends mostly on westerly and southwesterly advections from Atlantic Ocean that produce annual amounts decreasing gradually from west to east and changes in seasonal rainfall from the winter maximum on the Portuguese coastland and in southwestern areas of Spain, to a bimodal regime with a spring maximum in inland Spain (de Luis et al., 2010).

\subsection{Database}

The precipitation, runoff, erosion, and sediment yield database contains records of 11 small catchments and 26 experimental plots from 16 sites. Their locations are shown in Fig. 1, and Table 1 gives a brief description and an overview of their principal 
characteristics (see reference for details). Original data were collected using different instruments (i.e., erosion pins, Gerlach collectors, and gauging stations), from a variety of land uses and soil conditions, with different spatial and temporal scales. Measurement periods vary from 1 to 20 years. The database contains 5199 events with runoff and soil degradation. To avoid confusion, the text divides data on soil degradation into soil erosion (plot data from experimental sites) and sediment yield, SY (catchment data). We have homogenized the individual data set following the same criteria in all the cases and checking carefully for inconsistencies and odd data.

Some of the sites are located in temperate, humid, oceanic climate conditions to the north (Corbeira, Aixola, Añarbe, and Barrendiola catchments). Others are found in a variety of Mediterranean and subMediterranean climates in central, southern and eastern areas (Conchuela, Setenil, Puente Genil, Riera de Vernegà, and Barranca de los Pinos catchments; El Pinarillo and El Ardal experimental sites), including mountain areas in the Pyrenees (Aisa experimental site and Araguás catchment). Finally another group represents semiarid inland climate conditions to the northeast Ebro basin (Bardenas, Lanaja, Mediana, and La Puebla experimental sites). The spatial distribution of study sites covers all the spatial varieties of WTs and precipitation relationships presented by Cortesi et al. (2013); therefore, this data set is a promising sample of soil degradation research sites across the IP with which to verify the hypotheses previously indicated.

Finally, note that this database for soil degradation throughout Spain has been collected over long periods by different research groups belonging to the National Research Council (CSIC) and several universities, mostly with financial support from European, national, and regional governments.

\subsection{Weather type database}


The WT classification in this research relies on the daily pressure data from the NMC/NCAR 40-Year Reanalysis Project (Kalnay et al., 1996) and covers 1970-2012. Our approach to daily WT classification used the set of indices adopted by Trigo and DaCamara (2000), originally proposed by Lamb (1972), following the corresponding objective classification defined for the British Isles by Jenkinson and Collison (1977), which takes into account physical and geometric characteristics (see detailed formulation in Trigo and DaCamara, 2000, and Cortesi et al., 2013).

The original classification defines 26 different WTs, with eight WTs being purely directional types (NE, E, SE, S, SW, W, NW, and N); two WTs dominated by the strength of vorticity (cyclonic C and anticyclonic A types); and the remaining 16 WTs are hybrid types (eight for each $\mathrm{C}$ or A). However, it is often recommended to use classifications with a smaller number of WTs (Cortesi et al., 2013), so we reclassified the hybrid types into directional WTs, based on showing only where the air mass comes from and enters the IP. In the end, we used eight directional and two pure types (i.e. A, C, N, NE, E, SE, S, SW, W, NW).

The WTs have been calculated following the Trigo and DaCamara (2000) scheme. Thus, using the sea level pressure grid from Reanalysis, WT daily time series were calculated at each of the 12 NCAR pressure points corresponding to 12 pixel of the Reanalysis located in the IP (Fig. 2). For each erosion research station we selected the nearest WT point classification in order to analyze the relationships with erosion and sediment yield by site as accurately as possible. Following the WT nodes present in Fig. 2, the assignment was as follows: (i) the Corbeira catchment was compared with the WT from point 1; (ii) Aixola, Barrendiola, and Añarbe catchments with WTs from point 3; (iii) central Pyrenees and Ebro valley sites with the WT from point 4; (iv) Riera de Venergà catchments with WTs from point 5; (v) Barranca de los Pinos catchment with 
WTs from point 7; (vi) Puente Genil, Setenil, and Conchuela catchments with WTs from point 11; and finally (vii) El Ardal and Pinarillo sites with WTs from point 12.

\subsection{Analysis}

We tested the representativeness of the temporal frame in which erosion and SY were recorded at each location, as the lengths of records differ from site to site. This was done by applying the Kolmogorov-Smirnov test to compare the daily precipitation distribution of WTs from the nearest weather stations in the AEMet data set (Spanish National Meteorological Agency) with that of daily WT precipitation distribution recorded in the study sites. Next, we evaluated the daily relationships between WTs and runoff, soil erosion, and SY site by site estimating the percentage of runoff and soil degradation under WTs.

A magnitude-frequency analysis was developed to find how sediment yield was produced under different WTs. Following Wolman and Miller (1960), Thornes and Brunsden (1977), and Thorn (1988) we defined magnitude as the amount of sediment removed by events of a given frequency and calculated the work done as the product of magnitude and frequency. Thus, we evaluated the efficiency/effectiveness of WTs on sediment transport as the product of magnitude and frequency across the IP.

\section{Results}

\subsection{Precipitation and WTs}

The results of the Kolmogorov-Smirnov test showed no significant statistical differences $(p<0.05)$ between the frequency distribution of precipitation (in percentages) according to WTs in long-term records from the AEMet stations and precipitation distribution recorded at the study sites during the research periods (these 
data are not shown in the manuscript). These analyses basically answered two main questions: (i) they corroborated the strong association between WTs and precipitation patterns across the IP, and also (ii) the representativeness of the different periods included in the study areas.

As expected, the most frequent daily WTs corresponded to the pure anticyclonic type (A) in all cases followed by easterly flows (E, NE), northerly (N), and westerly (W) types (data not shown). These results generally coincide with those presented by Cortesi et al. (2014) in Spain. On the other hand, the days with the highest probability of rain usually occur under the cyclonic type; but in northern, central, and southern areas of the IP, precipitation is highly probable under westerly WTs (SW, W), while in eastern inland areas and along the Mediterranean fringe easterly (E, SE) flows are highly probable as a precipitation generator. Atmospheric mean configuration (synoptic charts) for different WT can be found in Cortesi et al. (2014)

The percentage of precipitation differs noticeably between sites and WTs across the IP, and this is a clear expression of its spatial differences in terms of genetic processes and air mass origins. Table 2 shows the percentage of precipitation under specific WTs. The cyclonic (C) is the most generalized WT producing a high percentage of precipitation across the IP, and the anticyclonic WT usually produces the lowest amount of precipitation; except in the Añarbe and Corbeira catchments the percentage of annual precipitation under $\mathrm{C}$ type is over $15 \%$. The relationship between precipitation and directional types shows spatial differences.

Westerly and northerly flows (i.e., N, NE, NW, SW, and W) relate to precipitation across the IP. The most generalized effects arise under W type except in the northeastern IP (Riera de Vernegà) and the southeastern (El Ardal) and northeastern inland areas of IP in the Ebro basin (Lanaja and Mediana sites). Under the W type, 
percentages of precipitation exceed $10 \%$ and can reach $>30 \%$ (Corbeira and La Conchuela catchments). The SW and NW types are also prominent and can produce similar or higher percentages of precipitation than the W type, but their effects are not so generalized. The SW flow produces percentages of precipitation higher than $20 \%$ in northwestern (Corbeira site) and southern areas (La Conchuela, Puente Genil, Setenil, and El Pinarillo sites); also there is a significant contribution (>15\%) in the mountain areas of the central Pyrenees. On the other hand, the NW type mainly affects the northern coastland areas (Corbeira, Aixola, Añarbe, and Barrendiola catchments), the Pyrenees (Araguás and Aisa sites), and central plains (Barranca de los Pinos catchment), with a percentage of $>10 \%$. This WT is not strongly linked to precipitation $(<10 \%)$ in the eastern part of the IP (Ebro basin sites: Bardenas, Lanaja, Mediana, La Puebla), or Mediterranean coastland sites (Vernegà and El Ardal), and some sites to the south (La Conchuela and Puente Genil). A pure $\mathrm{N}$ flow also contributes a high percentage to annual precipitation, but their effects are more widely distributed and only make a > $10 \%$ contribution in northern (Aixola, Añarbe, and Barrendiola catchments) and northeastern areas (Riera de Vernegà) of the peninsula.

A second set of WTs are easterly flows whose effects seem to be more localized. The NE flows produce more than $10 \%$ of precipitation in specific areas of northern IP (Aixola, Barrendiola, and Añarbe catchments) and also to the extreme southeast (El Ardal experimental site). The E flow contribution to total precipitation exceeds $10 \%$ in the northeastern inland Ebro basin (Lanaja, Mediana, and La Puebla sites), southeast (El Ardal site), and some sites to the south (Puente Genil catchment). Also, precipitation rises to $>10 \%$ under the SE flow in northeastern areas (inland Ebro basin: Lanaja, Mediana, and La Puebla sites; coastland: Riera de Venergà). 
It is interesting to note that, in all cases, a high percentage of precipitation is concentrated in few WTs, meaning that a large amount of precipitation is caused by a few atmospheric conditions defined by WTs. In all the study sites, the WT with the maximum percentage of precipitation accounted for more than $25 \%$ of total precipitation. The two WTs with the highest contribution usually produce more than $40 \%$, and the three wettest WTs produce more than $60 \%$ of total precipitation in most of the sites (Table 2). These results are highly interesting because if climate models are able to reproduce the pressure fields we could be fairly confident that precipitation simulation would be spatially modeled reasonably well on an annual scale.

\subsection{Runoff and WTs}

In Table 3 and Fig. 3 we show the percentage of runoff produced under specific WTs. As expected, a high percentage of runoff generation occurs under a few WTs in a more limited way than precipitation, which means that only a fraction of total precipitation is converted to overland flow and runoff.

In conjunction with the cyclonic type, westerly and northerly flows predominate in the amount of runoff but differs depending on the relationship between the WT and precipitation. In northern, central, and southern areas, the SW type contributes with percentages of over $20 \%$ of total runoff (Corbeira, Aisa, La Conchuela, and Setenil sites) and reaches a maximum of $51.9 \%$ in Puente Genil; the NW contribution to runoff is over 20\% in northern areas (Añarbe, Aixola, and Barrendiola), central areas of IP (Barranca de los Pinos), and southern coastland (El Pinarillo experimental site) with a contribution that may reach $>40 \%$ locally. The contribution of the $\mathrm{W}$ type is also generalized and is usually over $10-20 \%$, i.e. not as high as SW and NW. The N pattern produces high percentages $(>25 \%$ ) in northern areas (Añarbe and Barrendiola sites, but 
not in the nearby Aixola catchment), and $>10 \%$ in northeast inland Ebro basin (Bardenas, Lanaja, and Mediana sites). These results suggest that precipitation has different characteristics under different WTs and that the final overland flow and runoff does not depend exactly on total precipitation but also on these characteristics (temporal distribution, intensity, etc.).

The easterly flows (NE, E, and SE) are also able to produce high percentages of runoff but in restricted and specific areas. The SE type causes a high percentage of runoff in the southeastern areas (El Ardal site, 24.8\%). It is noticeable that this WT is able to produce substantial amounts of runoff in northeast inland sites (Ebro basin: Lanaja, Bardenas, La Puebla, and Mediana sites). The NE pattern contributes with > $10 \%$ on total runoff in various northern sites ranging from the northern coastland (Barrendiola) to the inland Ebro basin (Bardenas and Lanaja) to the northeast coastland (Riera de Vernegà). Finally, the E type in the southeast (El Ardal) is the only one to produce over $10 \%$ runoff.

Generally speaking, the highest WT contributors usually produce $25 \%$ of total runoff, and the three highest WTs contribute more than $60 \%$ of total runoff, except in the northeast inland Ebro basin (Lanaja, La Puebla, Bardenas, and Mediana sites) and in the Aisa experimental station in the central Pyrenees (57.7\%). Again, a dichotomy seems to exist between westerly and easterly WTs and their effects on runoff generation, with the westerly pattern being more generalized than easterly ones.

\section{3. Soil erosion, sediment yield, and WTs}

The percentage of soil eroded or SY per site depending on the WT are presented in Table 4 and Fig. 4 (some examples are shown graphically). Once more, an extreme concentration of sediment production is observed for just a few WTs and a great many 
geomorphological processes occur under specific atmospheric conditions, but they do not correspond exactly to the percentages of runoff, which means that erosion and SY are processes that occur within a small temporal frame.

Soil erosion and SY are mostly dependent on westerly flows in western and northern areas of the IP, but no clear predominance as with runoff or precipitation occurs; also, the contribution from the $\mathrm{C}$ type is mostly in the south. In the northwest (Corbeira catchment), SW and $\mathrm{W}$ types produce $40 \%$ and $32 \%$ of total sediment, respectively. In the central IP (La Barranca de los Pinos catchment), the NW type produces $56.4 \%$. The NW type is also a high contributor to soil degradation in the northern Cantabrian coastland (Barrendiola, Añarbe, and Aixola catchments) with a percentage over $25 \%$; however, the northerly flow may be more important locally in this area $(45.6 \%$ in Añarbe and $19.9 \%$ in Barrendiola under the $\mathrm{N}$ type, and $38.2 \%$ in Barrendiola under the NE).

Westerly flows (W, SW, and NW) are also important contributors to soil degradation in the southwest, currently over $25 \%$ in La Conchuela and Puente Genil (SW) and Setenil catchments (W); the same is true for the SW type to the northeast highland mountains of the Pyrenees (Araguás sites, 28.5\%). Meanwhile, in the lowland areas of the Ebro valley (northeast inland), high variability is observed in the relationships between WTs and soil degradation and no pattern can be established; for example, easterly flows predominate in the Mediana site under the SE type (25.9\%), but the NW produces $23.9 \%$ in La Puebla.

Finally, a high percentage of soil erosion is produced under easterly flows in areas of the south and southeastern IP. In the El Pinarillo site, $61.8 \%$ of soil eroded is related to NE flows, and E flows are responsible for $32 \%$ of total soil eroded in the El Ardal 
site. The only site with a high percentage of soil eroded under the $\mathrm{S}$ type is Aisa $(18.4 \%)$ in the northeast of the IP.

Soil degradation is produced mostly under a few WT events that are not the most frequent. As a whole, the three WTs with high percentages of soil degradation accounted for more than $70 \%$ of soil eroded or sediment yielded (in some places even > 90\%), except in the northeastern area (Pyrenees and Ebro basin) in Aisa, Lanaja, Bardenas, La Puebla, and Mediana sites $(\approx 50 \%)$, and it is not uncommon for more than $50 \%$ of total sediment to be produced under a single WT. In general, these values are higher than those presented for runoff dependence on WTs, which is more spatially variable.

\subsection{Magnitude, frequency, and geomorphological work}

The analysis of the magnitude-frequency allows us to evaluate the efficiency of WTs on sediment transport site by site. The most efficient WTs in sediment production in the different study areas are westerly flows, although spatial differences exist (some graphical examples are in Fig. 5).

The westerly patterns (W, NW, and SW) show the highest efficiency on erosion and sediment transport. In the northwest (e.g. the Corbeira site), central (e.g. La Barranca de los Pinos), and northern coastland areas (e.g. the Aixola site) the maximum geomorphological work is done under a W or NW flow. In the central Pyrenees (e.g. the Araguás catchment), the pattern changes to SW, which is the same for the southern areas of the IP (e.g. La Conchuela and Puente Genil sites). Local effects and orography alignment seem to be the reason for NW flow efficiency in the El Pinarillo site in the south of the IP. 
In the northeast inland areas of the Ebro valley (Lanaja, Bardenas, La Puebla, and Mediana sites), no WT was found to be more prominent than the others; and geomorphological work seems to progress with no atmospheric conditions being preeminent (although pure WTs predominate). These areas seem to be transitional areas, i.e. climatic ecotone, from the point of view of atmospheric mechanisms that promote the geomorphological work. Finally, in the southeastern coastland, the most efficient WTs seem to be the cyclonic and E types (i.e. El Ardal experimental site).

\section{Discussion}

The inherent spatial variability of precipitation is a strong drawback to understanding spatial variability of soil degradation in the IP and to developing an efficient strategy to combat soil erosion and SY under scenarios of global climate change; thus, no global solution could be found, as the processes analyzed vary in both time and space. We have approached this problem in the IP by trying to identify the relationships between WTs and soil degradation (by means of soil erosion and sediment yield); and the results suggest that, apart from the high spatial variability of soil degradation in which local factors contribute in well-recognized ways (slope, land use, soil type, management, etc.), certain subregional generalized patterns have also emerged, i.e. over the IP as a whole, soil erosion and sediment yield are not spatial homogeneous processes, but demonstrate atmospheric patterns represented by WTs; these may well be a useful tool in preventing and combating land degradation.

Atmospheric circulation patterns, expressed as WTs, play an important role in precipitation distribution in the IP, and previous researchers have identified their general relationships (Queralt et al., 2009; Fernández-González et al., 2012; Cortesi et al., 2013). The detailed spatial analyses developed by Cortesi et al. (2014) revealed that the 
relationship between WTs and precipitation in widespread areas of the IP could be generalized. Examples are found in the northern Cantabrian coastland where $\mathrm{N}$ and NW flows were the most influential WTs, or in central, western, and southwestern IP where precipitation mostly relates to $\mathrm{C}, \mathrm{W}$, and $\mathrm{SW}$ types; finally, along the Mediterranean coastland and northeast inland areas, there was no definite relationship between precipitation and WTs (suggesting that local factors are exerting an effect), and precipitation was produced under a variety of easterly flows, particularly the E type (Goodess and Palutikof, 1998). These analyses concluded that just few wet WTs dominate precipitation over large parts of the IP, reaching more than $50 \%$ in the majority of the study areas (Trigo and DaCamara, 2000; Muñoz-Díaz and Rodrigo, 2006; Paredes et al., 2006; Cortesi et al., 2013). The results presented in this paper agree with previous analyses and confirm that precipitation depends on just a few WTs for each site across the IP; and consequently runoff, erosion, and SY are concentrated in a small number of WTs that vary spatially and that prove the main hypotheses of the research.

The surface pressure fields under cyclonic WTs are dominated by a low pressure center over the IP. The spatial distribution exhibits a diagonal orientation from NE to SW. Thus, precipitation in the northwestern and southeastern sectors of the IP does not fully relate to this WT. Westerly (W) patterns consist of a high pressure centered west of the Canary Islands and a low pressure system located just west of Ireland. The Atlantic westerly flows enter the IP from west to east without mountain barriers until they reach the Iberian range. Consequently, this pattern affects the western, central, and southern areas of the IP. Finally, the SW pattern consists of a low pressure center located to the west of Ireland but extending farther south than the W pattern. Further 
information on the spatial configuration of the remaining WTs can be found in Cortesi et al. $(2013,2014)$.

It is known that the variability of precipitation in western Europe could be related with patterns that describe the atmospheric circulation at larger spatial scales, like NAO, AO, EAWR, EA, etc. In the Iberian Peninsula particularly, the North Atlantic Oscillation seems to be the most important low frequency variability factor affecting precipitation in central-western areas (but not in the Mediterranean fringe, neither in north Cantabrian coastland) with a negative correlation with monthly precipitation particularly in winter. Meanwhile, the positive phase of the NAO is associated with an enhanced Azores anticyclone prevailing the entry of storms from the Atlantic ocean and low or absence of precipitation in the IP. Fernández-González et al. (2012) found that the increase in the NAO index in the last decades caused a decrease in the frequency of the three weather types responsible for most of the precipitation in the west of the IP, proving that the NAO controls winter precipitation in the west of the IP. Queralt et al. (2009) also concluded that NAO exerts a clear effect on the intensity of total and extreme precipitation rates in the northwest of the IP, whereas the frequency of precipitation is clearly affected by NAO in central and southwestern areas.

In the IP as a whole, three WTs accounted for more than $50 \%$ of total runoff and soil erosion in plots and sediment yield in catchments. Generally, the highest percentage of runoff, erosion, and SY is associated with westerly airflows, with the exception of the eastern part of the IP, including the inland Ebro valley in the northeast. These results suggest that runoff, erosion, and SY are highly dependent on a small number of atmospheric patterns; and the relationship presented in this paper once again demonstrates that there is temporal compression in soil degradation processes (see González-Hidalgo et al., 2009), i.e. runoff and soil degradation occur in a very small 
temporal frame and depends on a few atmospheric patterns that represent $<25 \%$ of total time. Our results are similar to those found by Pattison and Lane (2012), who indicated that only five WTs accounted for $>80 \%$ of the recorded extreme events in the River Eden (United Kingdom), and by Longfield and Macklin (1999) who showed that four WTs accounted for $79.7 \%$ of all runoff events in the Yorkshire Ouse catchment.

Climate scenarios are currently used to analyze future soil degradation. This research is based on a compromise between outputs from climate and erosion models, both of which are highly unreliable on a daily scale. The results presented in this paper suggest that a reasonable approach to the spatial variability of soil erosion and sediment yield on an annual scale, in an area with such highly variable precipitation as found in the IP, could be achieved by using the WTs approach because atmospheric pressure fields are usually reliably captured by climate models. Therefore, we suggest that the relationships between WTs and soil degradation described in this research could be a valuable tool for this downscaling exercise. Further research on this topic and focused on subregional landscape planning should be welcomed.

\section{Conclusions}

In the Iberian Peninsula we have proved the relationships between WTs, precipitation, runoff, soil erosion, and sediment yield and have detected the spatial differences that help to explain the nature of the spatial variability of soil degradation processes.

High percentages of precipitation occurred during the three rainiest WTs (NW, SW, and C), being (in general) cyclonic and westerly types. Moreover, most of the runoff and erosion or sediment yields were generated by westerly types (namely SW, NW, and W), with the exception of the Mediterranean coast where easterly flows predominate. 
In general, the most efficient WTs in sediment production in the various study areas are westerly in the midwestern areas of the IP and demonstrate a cyclonic and easterly atmospheric pattern inland to the east.

The analyses of the percentage contribution to runoff and soil degradation under different WTs suggest that (i) a few atmospheric conditions are responsible for a large amount of runoff and soil degradation, (ii) a small amount of precipitation is converted to runoff, (iii) more than $50 \%$ of runoff and soil degradation is produced by only three WTs that vary spatially, and (iv) the highest runoff and soil degradation events do not belong to the same WT.

The results suggest that the weather types approach provides an easy system to understand the atmospheric patterns responsible for soil degradation and could be a valuable approach that would be worth exploring in future research on soil degradation in the IP.

\section{Acknowledgements}

Support for this research was provided by the projects: HIDROCAES (CGL201127574-C02-01 and 02), INDICA (CGL2011-27753-CO2-01 and 02), and CGL201021754-C02-01 of the Spanish Ministry of Science and Technology funded by the Spanish Ministry of Economy and Competition and FSE. Thanks to the AEMeT for the rainfall data, and to Roberto Serrano for his helpful assistance in the precipitation analysis. Thanks to the reviewers and the editor for their detailed work to improve your manuscript. E. Nadal-Romero was the recipient of a research contract (Spanish Ministry of Economy and Competition, Programme Juan de la Cierva), and now she is a Marie Curie postdoctoral researcher supported by the UE (project "MED-AFFOREST" PIEFGA-2013-624974). 


\section{References}

Andrade, C., Santos, J.A., Pinto, J.G., Corte-Real, J., 2011. Large-scale atmospheric dynamics of the wet winter 2009-2010 and its impact on hydrology in Portugal. Clim. Res. 46 (1), 29-41.

Bakker, M., Govers, G., van Doorn, A., Quetier, F., Chouvardas, D., Rounsevell, M., 2007. The response of soil erosion and sediment export to land-use change in four areas of Europe. The importance of landscape pattern. Geomorphology 98 (3-4), 213 226.

Biggs, E.M., Atkinson, P.M., 2011. A characterization of climate variability and trends in hydrological extremes in the Severn Uplands. Int. J. Climatol. 31 (11), 1634-1652.

Cortesi, N., Trigo, R.M., González-Hidalgo, J.C., Ramos, A.M., 2013. Modelling monthly precipitation with circulation weather types for a dense network of stations over Iberia. Hydrol. Earth Syst. Sci. 17, 665-678.

Cortesi, N., Gonzalez-Hidalgo, J.C., Trigo, R.M., Ramos, A.M., 2014. Weather types and spatial variability of precipitation in the Iberian Peninsula. Int. J. Climatol. Doi: 10.1002/joc. 3866 .

de Castro, M., Martin-Vide, J., Alonso, S., 2005. El clima de España: pasado, presente y escenarios de clima para el siglo XXI. In: Impactos del cambio climático en España, Ministerio Medio Ambiente, Madrid.

de Luis, M., Brunetti, M., González-Hidalgo, J.C., Longares, L.A., Martín-Vide, J., 2010. Changes in seasonal precipitation in the Iberian Peninsula during 1946-2005. Glob. Planet. Change 74 (1), 27-33.

Desir, G., Marin, C., 2007. Factors controlling the erosion rates in a semi-arid zone (Bardenas Reales, NE Spain). Catena 71 (1), 31-40. 
Desir, G., Sirvent, J., Gutierrez, M., Sancho, C., 1995. Sediment yield from gypsiferous degraded areas in the middle Ebro basin (NE, Spain). Phys. Chem. Earth 20 (3-4), 385-393.

Fernández-González, S., del Río, S., Castro, A., Penas, A., Fernández-Raga, M., Calvo, A.I., Fraile, R., 2012. Connection between NAO, weather types and precipitation in León, Spain (1948-2008). Int. J. Climatol. 32 (14), 2181-2196.

Fernández-Raga, M., Fraile, R., Keizer, J.J., Varela Teijeiro, M.E., Castro, A., Palencia, C., Calvo, A.I., Koenders, J., Da Costa Marques, R.L., 2010. The kinetic energy of rain measured with an optical disdrometer: An application to splash erosion. Atmos. Res. 96 (2-3), 225-240.

Fleig, A.K., Tallaksen, L.M., Hisdal, H., Hannah, D.M., 2011. Regional hydrological drought in North-western Europe: linking a new Regional Drought Area Index with weather types. Hydrol. Process. 25 (7), 1163-1179.

Foulds, S.A., Macklin, M.G., Brewer, P.A., 2014. The chronology and the hydrometeorology of catastrophic floods on Dartmoor South West England. Hydrol. Process. 28 (7), 3067-3087. Doi: 10.1002/hyp.9853.

Fournier, F. 1960. Climat et érosion. Presses Universitaires de France: Paris.

Fraile, R., Monsalve, F., Tomás, C., 2013. Influence of meteorological parameters and air pollutants onto the morbidity due to respiratory diseases in Castilla-La Mancha, Spain. Aerosol Air Qual. Res. 13 (4), 1297-1312.

García Ruiz, J.M., López-Bermúdez, F., 2009. La erosión del suelo en España. Sociedad Española de Geomorfología. Zaragoza.

Gómez, J.A., Vanwalleghem, T., De Hoces, A., Taguas, E.V., 2014. Hydrological and erosive response of a small catchment under olive cultivation in a vertic soil during a 
five year period: implications for sustainability. Agric. Ecosyst. Environ. 188, 229244.

González-Hidalgo, J.C., de Luis, M., Batalla, R.J., 2009. Effects of the largest daily events on total soil erosion by rainwater. An analysis of the USLE database. Earth Surf. Process. Landf. 34 (15), 2070-2077.

González-Hidalgo, J.C., Brunetti, M., de Luis, M., 2011. A new tool for monthly precipitation analysis in Spain: MOPREDAS database (monthly precipitation trends December 1945-November 2005). Int. J. Climatol. 31 (5), 715-731.

Goodess, C.M., Palutikof, J.P., 1998. Development of daily rainfall scenarios for the southeast Spain using a circulation type approach to downscaling. Int. J. Climatol. 18 (10), 1051-1081.

Grove, A.T., Rackham, O., 2001. The Nature of Mediterranean Europe: An Ecological History. Yale University Press, London.

Jenkinson, A.F., Collison, F.P., 1977. An initial climatology of gales over the North Sea, Synoptic Climatology Branch Memorandum, No. 62, Meteorological Office, Bracknell.

Kalnay, E., Kanamitsu, M., Kistler, R., Collins, W., Deaven, D., Gandin, L., Iredell, M., Saha, S., White, G., Woollen, J., Zhu, Y., Chelliah, M., Ebisuzaki, W., Higgins, W., Janowiak, J., Mo, KC., Ropelewski, C., Wang, J., Leetmaa, A., Reynolds, R., Jenne, R., Joseph, D., 1996. The NMC/NCAR 40-Year Reanalysis Project. Bull. Amer. Meteor. Soc. 77: 437-471.

Lamb, H.H., 1972. British Isles Weather Types and a Register of Daily Sequence of Circulation Patterns. Geophysical Memoir, vol. 116. HMSO, London, pp. 1861-1971. 
Longfield, S.A., Macklin, M.G., 1999. The influence of recent environmental change on flooding and sediment fluxes in the Yorkshire Ouse basin. Hydrol. Process. 13 (7), 1051-1066.

López-Moreno, J.I., Vicente-Serrano, S., 2007. Atmospheric of circulation influence of the interannual variability of snowpack in the Spanish Pyrenees during the second half of the 20th century. Nordic Hydrology 38 (1), 33-44.

Lorenzo, M.N., Taboada, J.J., Lorenzo, J.F., Ramos, A.M., 2013. Influence of climate on grape production and wine quality in the Rías Baixas, north-western Spain. Reg. Envir. Chang. 13 (4), 887-896.

Lucía, A., Laronne, J.B., Martín-Duque, J.F., 2011. Geodynamics processes on Sandy slope gullies in central Spain field observations, methods and measurements in a singular system. Geodin. Acta 24/2, 61-79.

Muñoz-Díaz, D., Rodrigo, F.S., 2006. Seasonal rainfall variations in Spain (1912-2000) and their links to atmospheric circulation. Atmos. Res. 81 (1), 94-110.

Nadal-Romero, E., Reguiés, D., 2010. Geomorphological dynamics of subhumid mountain badland areas - weathering, hydrological and suspended sediment transport processes: A case study in the Araguás catchment (Central Pyrenees) and implications for altered hydroclimatic regimes. Prog. Phys. Geogr. 34 (2), 123-150.

Nadal-Romero, E., Lasanta, T., García-Ruiz, J.M., 2013. Runoff and sediment yield from land under various uses in a Mediterranean mountain area: long-term results from an experimental station. Earth Surf. Process. Landf. 38 (4), 346-355.

Nadal-Romero, E., Cortesi, N., González-Hidalgo, J.C., 2014. Weather types, runoff and sediment yield in a Mediterranean mountain landscape. Earth Surf. Process. Landf. 39 (4), 427-437. Doi: 10.1002/esp.3451. 
Outeiro, L., Úbeda, X., Farguell, J., 2010. The impact of agriculture on solute and suspended sediment load on a Mediterranean watershed after intense rainstorms. Earth Surf. Process. Landf. 35 (5), 549-560.

Paredes, D., Trigo, R.M., García-Herrera, R., Trigo, I.F., 2006. Understanding precipitation changes in Iberia in early spring: weather typing and storm-tracking approaches. J. Hydrometeorol. 7 (1), 101-113.

Pattison, I., Lane, S.N., 2012. The relationship between Lab weather types and longterm changes in flood frequency, River Eden, UK. Int. J. Climatol. 32 (13), 19711989.

Piotrowicz, K., Szlagor, J., 2013. The link between from day to day change of weather types and synoptic situations in Kraków during the period 1961-2010. Quaestiones Geographicae 32 (3), 69-84.

Queralt, S., Hernández, E., Barriopedro, D., Gallego, D., Ribera, P., Casanova, C., 2009. North Atlantic Oscillation influence and weather types associated with winter total and extreme precipitation events in Spain. Atmos. Res. 94 (4), 675-683.

Rivas-Soriano, L., Tomás, C., de Pablo, F., García, E., 2013. Circulation weather types and wildland forest fires in the western Iberian Peninsula. Int. J. Climatol. 33 (6), 1401-1408.

Rodríguez-Blanco, M.L., Taboada-Castro, M.M., Taboada-Castro, M.T., 2013. Linking the field to the stream: Soil erosion and sediment yield in a rural catchment, NW Spain. Catena 102, 74-81.

Romero-Díaz, A., Cammeraat, L.H., Vacca, A., Kosmas, C., 1999. Soil erosion at three experimental sites in the Mediterranean. Earth Surf. Process. Landf. 24 (13), 12431256. 
Ruiz-Sinoga, J.D., Hueso-González, P., Martínez-Murillo, J.F., 2013. Aproximación al proceso de interceptación en una ladera del sur de España (Nerja). In: Instituto Euromediterráneo del Agua (Eds.), Interceptación de la lluvia por la vegetación en España, Fundación Instituto Euromediterráneo del Agua, Murcia, pp. 337-359.

Rust, H.W., Vrac, M., Sultan, B., Lengaigne, M., 2013. Mapping weather types influence on Senegal Precipitation based on spatial-temporal statistical model. J. Clim. $26(20), 8189-8209$.

Sirvent, J., Desir, G., Gutierrez, M., Sancho, C., Benito, G., 1997. Erosion rates in badland areas recorded by collectors, erosion pins and profilometer techniques ( Ebro Basin, NE-Spain). Geomorphology 18, 61-75.

Sturman, A., Quenol, H., 2013. Changes in atmospheric circulation and temperature trends in major vineyard regions of New Zealand. Int. J. Climatol. 33 (12), 2609-2621.

Taguas, E.V., Ayuso, J.L., Peña, A., Yuan, Y., Pérez, R., 2009 Evaluating and modelling the hydrological and erosive behavior of an olive orchard microcatchment under no-tillage with bare soil in Spain. Earth Surf. Process. Landf. 34 (5), 736-751.

Taguas, E.V., Carpintero, E., Ayuso, J.L., 2013 Assessing land degradation risk through the long-term analysis of erosivity: A case study in Southern Spain. Land Degrad. Dev. 24 (2), 179-187.

Thorn, E., 1988. Introduction to Theoretical Geomorphology. Allen \& Unwin: Winchester.

Thornes, J.B., Brunsden, D., 1977. Geomorphology \& Time. Methuen \& Co Ltd: London.

Trigo RM, DaCamara C., 2000. Circulation weather types and their influence on the precipitation regime in Portugal. Int. J. Climatol. 20 (13), 1559-1581. 
Trigo, R.M., Sousa, P.M., Pereira, M.G., Rasilla, D., Gouveia, C.M., 2013. Modelling wildfire activity in Iberia with different atmospheric weather types. Int. J. Climatol. doi: 10.1002/joc.3749.

Vanos, J.K., Hebbern, C., Cakmak, S., 2014. Risk assessment for cardiovascular and respiratory mortality due to air pollution and synoptic meteorology in 10 Canadian cities. Environ. Pollut. 185, 322-332.

Vicente-Serrano, S., López-Moreno J.I., 2006. The influence of atmospheric circulation at different spatial scales on winter drought variability. Int. J. Climatol. 26 (11), $1427-$ 1453.

Wilby, R.L., Quinn, N., 2013. Reconstructing multi-decadal variations in fluvial flood risk using atmospheric circulation patterns. J. Hydrol. 487, 109-121.

Wilby, R.L., Dalgleish, H.Y., Foster, I.D.L., 1997. The impact of weather patterns on historic and contemporary catchment sediment yields. Earth Surf. Process. Landf. 22 (4), 353-363.

Wischmeier, W.H., Smith, D.D., 1958. Rainfall energy and its relationship to soil loss. Trans AGU 39, 285-291.

Wolman, M.G., Miller, J.P., 1960. Magnitude and frequency of forces in geomorphic processes. J. Geol. 68 (1), 54-74.

Zabaleta, A., Martínez, M., Uriarte, J. A., Antigüedad, I., 2007. Factors controlling suspended sediment yield during runoff events in small headwater catchments of the Basque Country. Catena 71 (1), 179-190. 


\begin{tabular}{|c|c|c|c|c|c|c|c|c|c|}
\hline \multicolumn{2}{|l|}{ Study area } & Methods & Area $\left(\mathrm{km}^{2}\right)$ & $\begin{array}{l}\text { Altitude } \\
(\mathrm{m} \text { asl })\end{array}$ & $\begin{array}{l}\text { Gradient } \\
(\%)\end{array}$ & $\begin{array}{l}\text { Study } \\
\text { period }\end{array}$ & Events & Observations & Reference \\
\hline \multicolumn{2}{|l|}{ Corbeira } & Catchment & 16 & $60-470$ & 2.9 & 2005-2012 & 226 & $\begin{array}{l}\text { Rural area with eucalyptus } \\
\text { forest and agricultural land }\end{array}$ & Rodríguez -Blanco et al., 2013 \\
\hline \multicolumn{2}{|l|}{ La Conchuela } & Catchment & 0.14 & 147 & 9 & $2006-2011$ & 111 & & Gómez et al., 2014 \\
\hline \multicolumn{2}{|l|}{ Puente Genil } & Catchment & 0.061 & 239 & 15 & 2005-2011 & 73 & $\begin{array}{l}\text { Arroyo Blanco. Olive trees } \\
\text { were planted in } 1999\end{array}$ & Taguas et al., 2013 \\
\hline \multicolumn{2}{|l|}{ Setenil } & Catchment & 0.067 & 782 & 10 & 2005-2011 & 121 & La Manga & Taguas et al., 2009 \\
\hline \multicolumn{2}{|l|}{ Pinarillo } & Plots & 0.000024 & 470 & 8 & 2011-2013 & 20 & $\begin{array}{l}32 \text { plots with different land } \\
\text { uses }\end{array}$ & Ruiz-Sinoga et al., 2013 \\
\hline \multicolumn{2}{|l|}{ Aixola } & Catchment & 4.8 & $340-750$ & $<30$ & 2003-2013 & 221 & $\begin{array}{l}\text { It is mostly (> } 80 \% \text { ) woodland } \\
\text { with Pinus radiata. }\end{array}$ & Zabaleta et al., 2007 \\
\hline \multicolumn{2}{|l|}{ Añarbe } & Catchment & 48 & $532-1035$ & $50-100$ & 2003-2005 & 17 & $\begin{array}{l}\text { It is covered with reforested } \\
\text { and mature Pinus nigra and } \\
\text { autochthonous vegetation }\end{array}$ & \\
\hline \multicolumn{2}{|l|}{ Barrendiola } & Catchment & 3 & $550-840$ & $20-50$ & 2003-2005 & 25 & $\begin{array}{l}\text { Autochthonous vegetation } \\
\text { (Fagus) and reforestation }\end{array}$ & \\
\hline \multicolumn{2}{|c|}{ Barranca de los Pinos } & Catchment & 0.0132 & 1050 & $>30$ & 2010 & 13 & $\begin{array}{l}\text { Badlands cover part of the } \\
\text { catchment }\end{array}$ & Lucía et al., 2011 \\
\hline \multicolumn{2}{|l|}{ Aisa } & Plots & 0.00003 & 1140 & 30 & 1995-2012 & 391 & $\begin{array}{l}7 \text { closed plots with different } \\
\text { land covers and traditional } \\
\text { practices }\end{array}$ & Nadal-Romero et al., 2013 \\
\hline \multicolumn{2}{|l|}{ Araguás } & Catchment & 0.45 & $780-1105$ & 20 & $2005-2013$ & 253 & $\begin{array}{l}\text { Badlands cover the lower part } \\
\text { of the catchment }\end{array}$ & $\begin{array}{l}\text { Nadal-Romero and Reguiés, } \\
2010\end{array}$ \\
\hline Bárdenas & $\begin{array}{l}1 \\
2\end{array}$ & Plots & 0.0004 & 340 & $\begin{array}{l}9 \\
34\end{array}$ & 1993-2004 & $\begin{array}{l}116 \\
89\end{array}$ & $\begin{array}{l}\text { Facing NE } \\
\text { Facing W }\end{array}$ & Desir and Marin, 2007 \\
\hline Lanaja & $\begin{array}{l}1 \\
2\end{array}$ & Plots & $\begin{array}{l}0.000257 \\
0.000218\end{array}$ & 335 & $\begin{array}{l}5 \\
23\end{array}$ & $1991-2003$ & $\begin{array}{l}157 \\
145\end{array}$ & $\begin{array}{l}2 \text { experimental plots in } \\
\text { Miocene continental shales }\end{array}$ & Sirvent et al., 1997 \\
\hline Mediana & $\begin{array}{l}\mathrm{N} \\
\mathrm{S}\end{array}$ & Plots & $\begin{array}{l}0.000066 \\
0.000050\end{array}$ & 360 & $\begin{array}{l}18 \\
24\end{array}$ & 1991-2004 & $\begin{array}{l}128 \\
124\end{array}$ & $\begin{array}{l}2 \text { experimental plots in } \\
\text { Miocene gypsum and marl } \\
\text { (north and south) }\end{array}$ & Desir et al., 1995 \\
\hline La Puebla & $\begin{array}{l}\mathrm{N} \\
\mathrm{S}\end{array}$ & Plots & 0.000054 & 300 & & 1991-2004 & $\begin{array}{l}183 \\
176\end{array}$ & $\begin{array}{l}2 \text { experimental plots in } \\
\text { Miocene gypsum and marl }\end{array}$ & Desir et al., 1995 \\
\hline El Ardal & & Plots & 0.000020 & 550 & 20 & 1989-2000 & 73 & $\begin{array}{l}17 \text { plots with different land } \\
\text { uses }\end{array}$ & Romero-Díaz et al., 1999 \\
\hline \multirow[t]{2}{*}{ Riera de Vernegà } & $\mathrm{F}$ & Catchment & 1.6 & $190-440$ & 5 & $1983-2012^{*}$ & 29 & Densely forested & Outeiro et al., 2010 \\
\hline & A & Catchment & 2.5 & $150-440$ & 5 & 1983-2012* & 41 & Agricultural practices & \\
\hline
\end{tabular}

Table 1. Runoff and sediment is measured from 1992-2012 and 2005-2012

respectively. 


\begin{tabular}{lcccccccccc}
\hline \% Precipitation & $\mathrm{A}$ & $\mathrm{C}$ & $\mathrm{N}$ & $\mathrm{NE}$ & $\mathrm{E}$ & $\mathrm{SE}$ & $\mathrm{S}$ & $\mathrm{SW}$ & $\mathrm{W}$ & $\mathrm{NW}$ \\
\hline Corbeira & 8.2 & 9.1 & 2.5 & 1.0 & 0.6 & 0.8 & 4.5 & 28.2 & $\mathbf{3 4 . 5}$ & 10.5 \\
La Conchuela & 4.0 & 16.7 & 7.3 & 2.2 & 2.7 & 2.8 & 2.9 & 21.2 & $\mathbf{3 3 . 1}$ & 7.1 \\
Puente Genil & 2.4 & 22.9 & 2.3 & 0.3 & 11.7 & 3.1 & 6.2 & $\mathbf{2 5 . 4}$ & 21.2 & 4.7 \\
Setenil & 3.7 & 18.9 & 5.7 & 3.2 & 3.7 & 3.6 & 4.4 & 19.0 & $\mathbf{2 4 . 5}$ & 13.2 \\
Pinarillo & 2.3 & $\mathbf{2 5 . 6}$ & 1.0 & 1.5 & 6.4 & 6.7 & 7.5 & 24.3 & 21.8 & 3.0 \\
Aixola & 5.1 & 16.4 & 18.2 & 13.0 & 3.4 & 1.2 & 1.6 & 5.0 & 13.6 & $\mathbf{2 2 . 5}$ \\
Añarbe & 8.0 & 12.9 & 22.1 & 11.7 & 2.8 & 0.7 & 0.9 & 3.6 & 12.5 & $\mathbf{2 4 . 9}$ \\
Barrendiola & 5.2 & 16.0 & 19.3 & 12.6 & 3.6 & 1.4 & 2.0 & 6.2 & 13.8 & $\mathbf{2 0 . 1}$ \\
Barranca de los Pinos & 4.5 & 17.2 & 9.9 & 5.0 & 5.0 & 2.2 & 1.9 & 9.5 & $\mathbf{2 5 . 2}$ & 18.4 \\
Aisa & 3.7 & 18.2 & 5.3 & 4.3 & 5.4 & 4.8 & 9.8 & 18.5 & $\mathbf{1 9 . 2}$ & 10.9 \\
Araguás & 3.9 & $\mathbf{2 0 . 9}$ & 3.6 & 4.1 & 6.8 & 5.3 & 9.9 & 17.3 & 18.0 & 10.3 \\
Bardenas & 3.4 & $\mathbf{2 6 . 8}$ & 5.8 & 3.3 & 8.4 & 10.4 & 10.1 & 13.8 & 10.1 & 8.1 \\
Lanaja & 4.5 & $\mathbf{2 6 . 3}$ & 3.2 & 7.4 & 14.1 & 10.2 & 9.8 & 13.7 & 8.3 & 2.5 \\
Mediana & 2.6 & $\mathbf{2 9 . 2}$ & 6.5 & 5.1 & 18.9 & 12.6 & 6.8 & 9.2 & 8.5 & 0.8 \\
La Puebla & 2.9 & $\mathbf{2 9 . 7}$ & 3.4 & 6.8 & 15.8 & 10.1 & 7.2 & 9.1 & 10.4 & 4.6 \\
El Ardal & 1.3 & $\mathbf{3 7 . 8}$ & 5.3 & 13.8 & 17.9 & 8.9 & 4.8 & 4.5 & 2.9 & 3.0 \\
Riera de Vernegà & 2.6 & $\mathbf{2 7 . 4}$ & 12.1 & 7.3 & 9.1 & 10.2 & 10.6 & 6.8 & 6.0 & 7.9 \\
\hline
\end{tabular}

Table 2. Percentage of precipitation and WTs for the different study areas (in bold: the maximum contributions) 


\begin{tabular}{|c|c|c|c|c|c|c|c|c|c|c|}
\hline$\%$ runoff & A & $\mathrm{C}$ & $\mathrm{N}$ & $\mathrm{NE}$ & $\mathrm{E}$ & SE & $\mathrm{S}$ & SW & $\mathrm{W}$ & NW \\
\hline Corbeision and SY & $4 \mathrm{~A} 2$ & 18.7 & 4.5 & $\mathrm{QE}$ & $\alpha \mathbf{B} 0$ & $8 \mathrm{BH}$ & $1 \mathrm{~S} 2$ & $38 \mathrm{M}$ & $2 \mathrm{~W} 2$ & 18.0 \\
\hline La Conchuela & 23.5 & 2.6 & 0.8 & 2.6 & 2.7 & 0.9 & 7.9 & 34.3 & 16.5 & 8.2 \\
\hline Puente Genil & 0.0 & 10.5 & 0.5 & 4.7 & 3.3 & 4.0 & 8.8 & 51.9 & 7.8 & 8.5 \\
\hline Setenil & 3.2 & 21.1 & 0.5 & 5.4 & 4.8 & 3.9 & 5.1 & 24.7 & 19.2 & 12.2 \\
\hline Pinarillo & 10.0 & 32.9 & 2.1 & 6.1 & 5.7 & 4.0 & 0.0 & 0.0 & 14.6 & 24.5 \\
\hline Aixola & 4.0 & 26.2 & 4.1 & 8.3 & 2.3 & 0.4 & 1.7 & 2.2 & 23.3 & 27.6 \\
\hline Añarbe & 25.6 & 2.8 & 25.3 & 0.0 & 1.5 & 0.0 & 0.1 & 0.0 & 3.2 & 41.4 \\
\hline Barrendiola & 0.0 & 9.1 & 31.2 & 22.6 & 0.0 & 0.0 & 0.1 & 8.4 & 1.6 & 27.1 \\
\hline Barranca de los Pinos & 0.0 & 21.0 & 4.6 & 0.0 & 0.0 & 0.8 & 0.0 & 0.0 & 28.9 & 44.7 \\
\hline Aisa & 2.4 & 16.7 & 5.9 & 1.6 & 5.8 & 3.5 & 19.5 & 21.5 & 12.6 & 10.4 \\
\hline Araguás & 6.0 & 26.4 & 2.2 & 2.8 & 1.0 & 4.9 & 4.9 & 14.1 & 21.4 & 16.4 \\
\hline Bardenas & 10.8 & 14.0 & 19.5 & 14.7 & 6.1 & 11.6 & 1.7 & 5.8 & 11.6 & 4.2 \\
\hline Lanaja & 21.0 & 9.2 & 10.6 & 13.6 & 5.8 & 7.4 & 5.7 & 9.0 & 9.4 & 8.4 \\
\hline Mediana de Aragón & 15.0 & 12.6 & 18.9 & 3.9 & 1.3 & 21.9 & 2.6 & 6.2 & 6.7 & 10.9 \\
\hline La Puebla & 19.1 & 3.8 & 7.8 & 5.4 & 1.8 & 18.9 & 4.0 & 7.2 & 13.6 & 18.4 \\
\hline El Ardal & 2.5 & 39.7 & 4.5 & 7.2 & 12.0 & 24.8 & 1.4 & 0.3 & 1.0 & 6.7 \\
\hline Riera de Venergà & 0.0 & 24.1 & 4.0 & 12.5 & 8.4 & 3.0 & 45.4 & 2.5 & 0.2 & 0.0 \\
\hline
\end{tabular}

Table 3. Contribution (\%) from different WTs to total runoff in the study areas (in bold the maximum contributions) 


\begin{tabular}{|c|c|c|c|c|c|c|c|c|c|c|}
\hline Corbeira & 3.8 & 11.8 & 2.8 & 0.7 & 0.0 & 0.0 & 1.3 & 40.3 & 32.6 & 6.6 \\
\hline La Conchuela & 37.4 & 1.3 & 1.2 & 2.4 & 1.9 & 0.7 & 9.3 & 29.0 & 9.8 & 6.9 \\
\hline Puente Genil & 0.0 & 16.5 & 0.3 & 6.9 & 4.1 & 0.7 & 5.8 & 46.3 & 10.0 & 9.5 \\
\hline Setenil & 0.9 & 38.3 & 0.4 & 1.2 & 2.4 & 2.2 & 3.3 & 15.7 & 27.9 & 7.9 \\
\hline Pinarillo & 5.6 & 29.9 & 4.0 & 1.5 & 5.8 & 0.6 & 0.0 & 3.4 & 34.5 & 14.7 \\
\hline Aixola & 3.8 & 15.1 & 1.9 & 8.5 & 0.7 & 0.2 & 13.9 & 1.1 & 25.9 & 28.8 \\
\hline Añarbe & 27.5 & 1.4 & 45.6 & 0.0 & 0.1 & 0.0 & 0.0 & 0.0 & 0.5 & 25.0 \\
\hline Barrendiola & 0.0 & 7.7 & 19.9 & 38.2 & 0.0 & 0.0 & 0.3 & 4.1 & 1.2 & 28.6 \\
\hline Barranca de los Pinos & 0.0 & 18.8 & 5.0 & 0.0 & 0.0 & 1.1 & 0.0 & 0.0 & 18.6 & 56.4 \\
\hline Aisa & 0.5 & 25.0 & 10.6 & 0.3 & 4.7 & 3.0 & 18.4 & 17.0 & 8.1 & 12.4 \\
\hline Araguás & 4.7 & 9.1 & 0.8 & 0.9 & 1.3 & 3.6 & 9.3 & 28.5 & 12.3 & 29.4 \\
\hline Bardenas & 9.8 & 18.9 & 17.2 & 13.5 & 5.3 & 9.7 & 2.7 & 6.0 & 13.5 & 3.3 \\
\hline Lanaja & 23.4 & 10.4 & 11.8 & 8.6 & 5.3 & 6.4 & 9.5 & 10.5 & 8.2 & 5.9 \\
\hline Mediana de Aragón & 11.6 & 14.0 & 16.9 & 3.9 & 1.1 & 25.9 & 2.1 & 5.0 & 4.7 & 14.9 \\
\hline La Puebla & 26.4 & 3.1 & 9.5 & 3.3 & 1.3 & 0.2 & 7.3 & 7.3 & 17.7 & 23.9 \\
\hline El Ardal & 1.4 & 42.8 & 1.4 & 6.7 & 32.1 & 10.3 & 0.8 & 0.2 & 0.2 & 4.1 \\
\hline Riera de Venergà $^{a}$ & 2.5 & 2.5 & 1.2 & 2.5 & 0.6 & 1.5 & 53.1 & 32.7 & 3.3 & 0.1 \\
\hline
\end{tabular}

Table 4. Contribution (\%) from different WTs to total erosion and SY in the study areas (in bold the maximum contributions)

${ }^{a}$ Refers to maximum sediment concentration. In bold the maximum contributions. 
Fig. 1. Study area location (catchments and plots) and views from the sites.

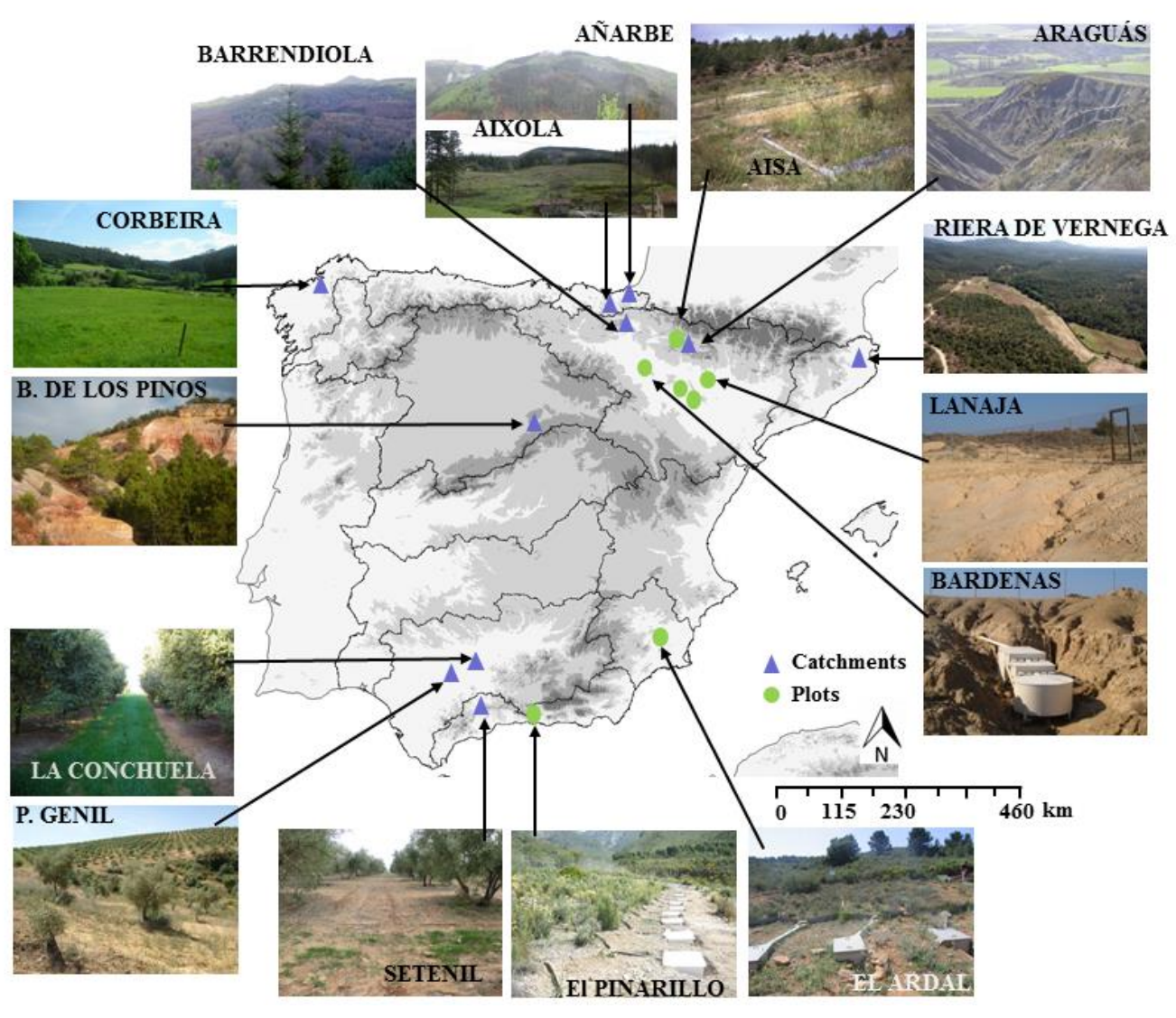


Fig. 2. Study areas and the corresponding NCAR grid points

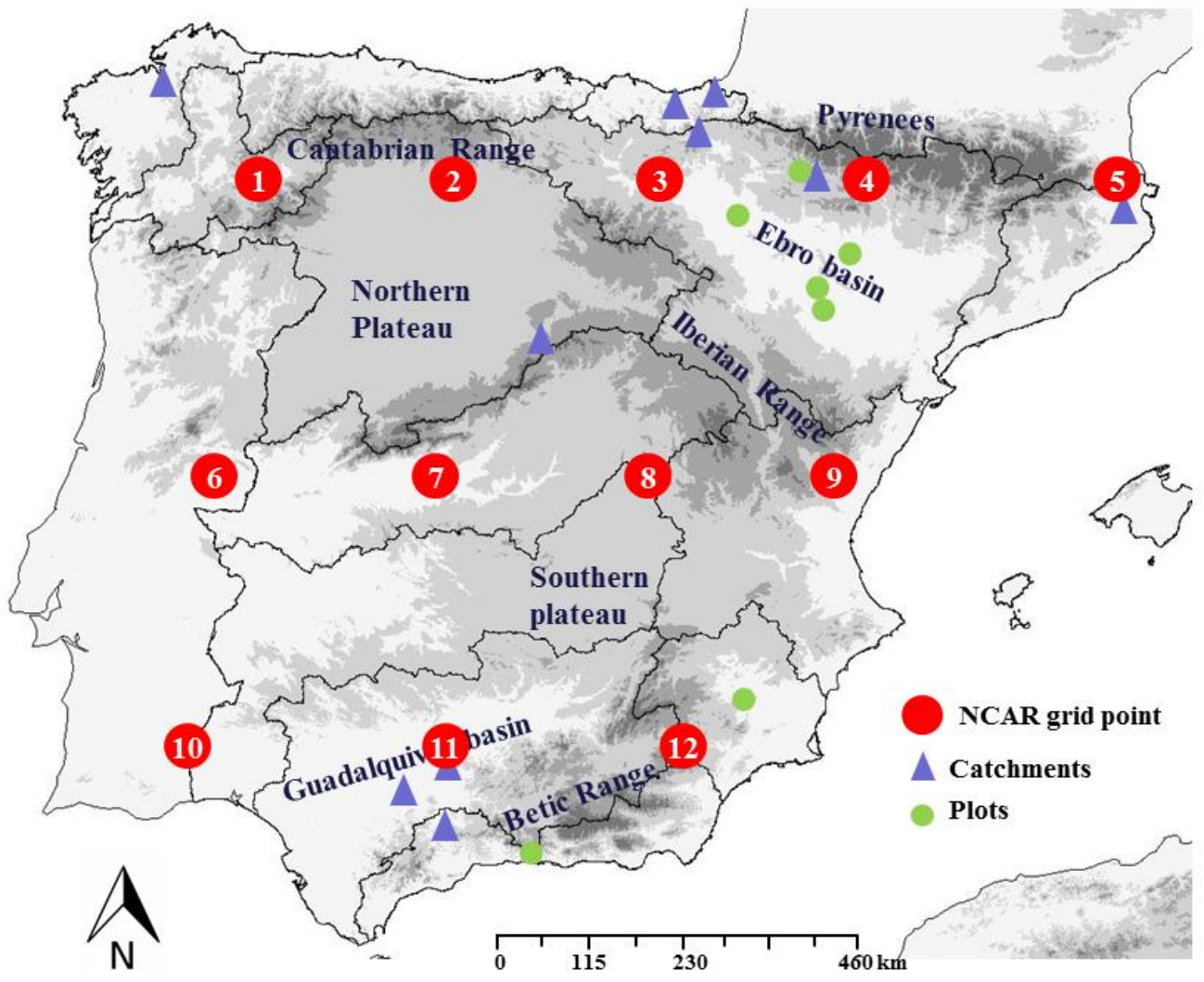


Fig. 3. Contribution (\%) from different WTs to total runoff in the selected study areas (to view all the data see Table 3).

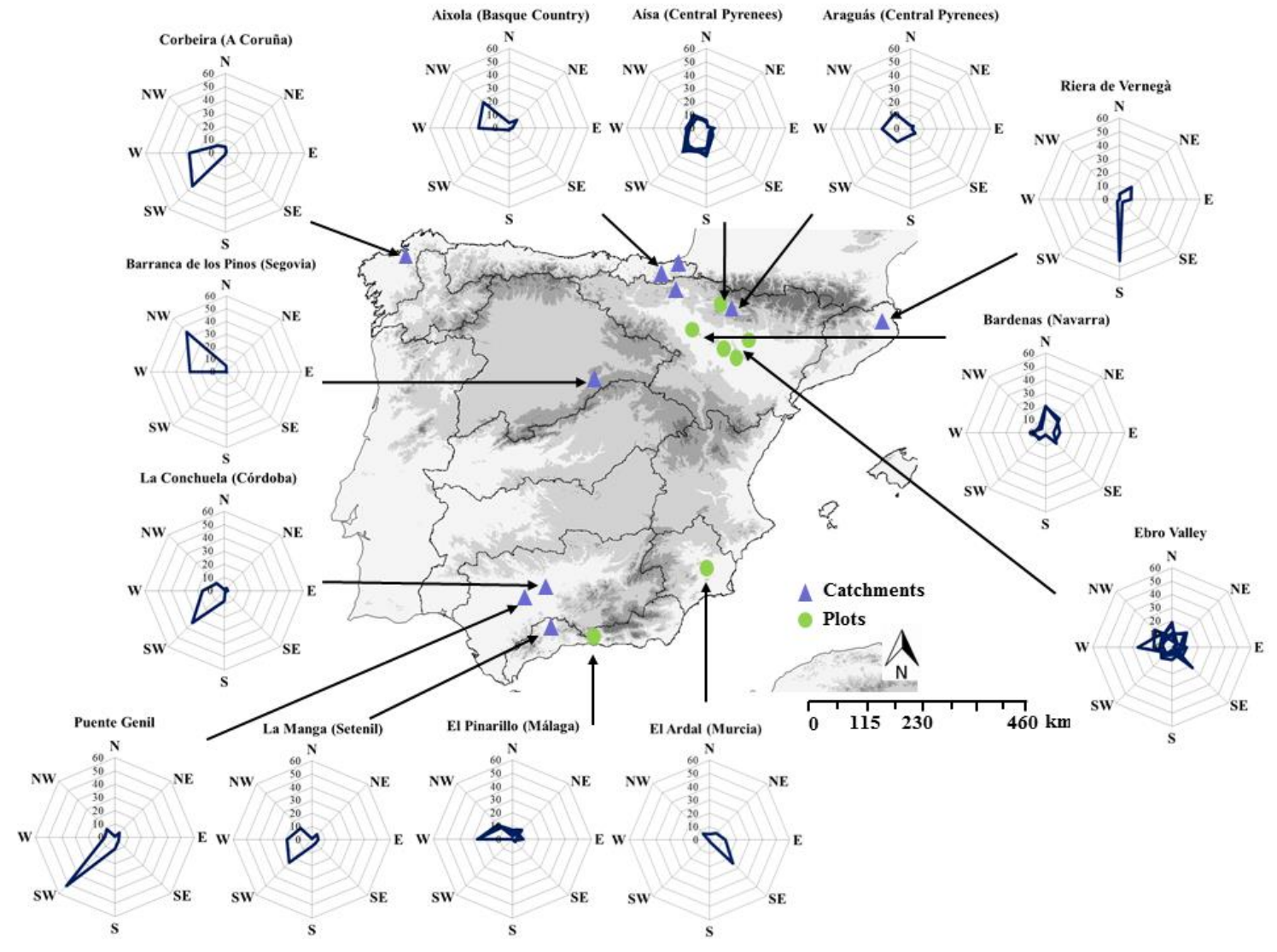


Fig. 4. Contribution (\%) from different WTs to total erosion rates and SY in the selected study areas (to view all the data see Table 4).

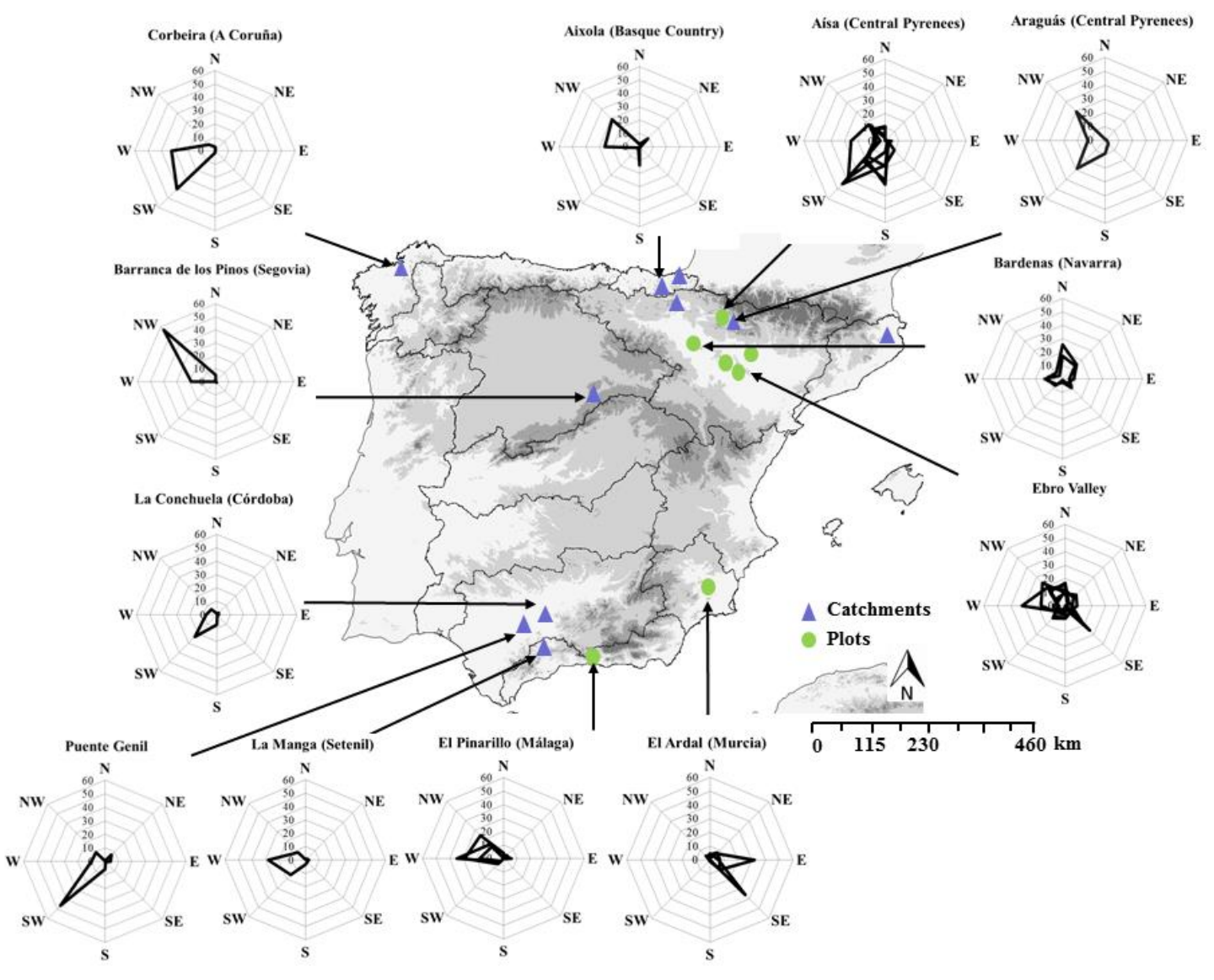


Fig. 5. Sediment and erosion from selected study areas and work done (magnitude, frequency) from different WTs. Grey bars correspond to total SY (Mg) by WT. Red line corresponds to the product of magnitude (grey bars) and frequency (not shown in the graph).

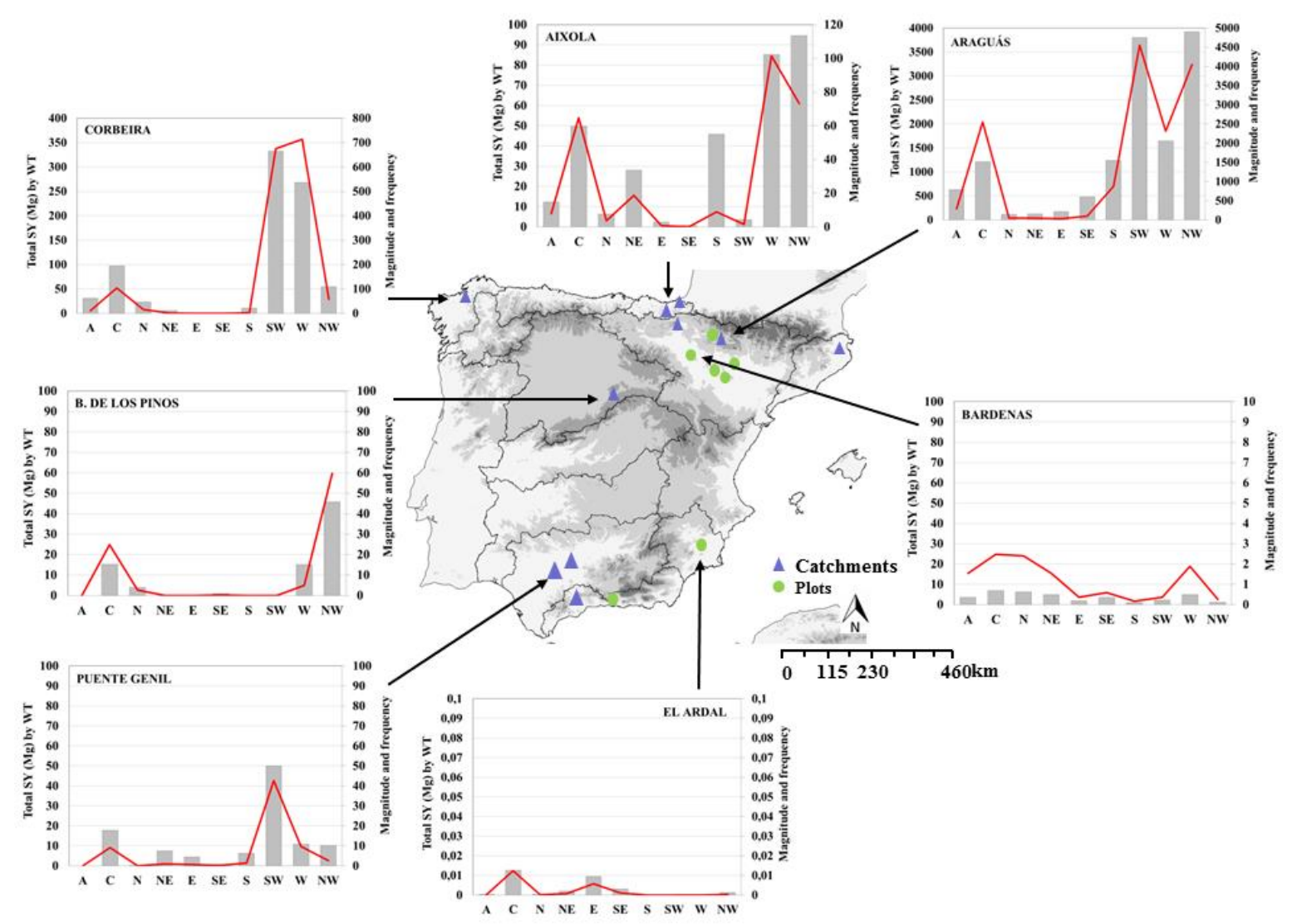

